\title{
A novel frameshift mutation in the XPC gene in a Moroccan patient: a case report

Yassamine Doubaj ${ }^{1,2^{*}}$, Wiam Smaili', Fatima-Zahra Laarabi ${ }^{1}$ and Abdelaziz Sefiani ${ }^{1,2}$

\begin{abstract}
Background: Xeroderma pigmentosum is an autosomal recessive inherited disease. The diagnosis is essentially based on clinical findings and the family history. This genodermatosis is genetically heterogeneous; to date, nine genes have been associated to this disorder. Based on the result of many studies, xeroderma pigmentosum complementation group $C$ is the most common form of xeroderma pigmentosum. A founder mutation in the XPC gene was reported in the Maghreb region of northern Africa. According to these findings, the Department of Medical Genetics in Rabat offers molecular diagnosis by screening for the recurrent mutation c.1643_1644delTG which represents 74\% of all the probands with xeroderma pigmentosum.
\end{abstract}

Case presentation: We describe the case of a 21-year-old Moroccan son of consanguineous parents diagnosed with xeroderma pigmentosum on the basis of sun-exposed skin abnormalities and bilateral ocular involvement. A molecular study led to the identification of a new frameshift insertion of four nucleotides in exon 9.

Conclusions: To the best of our knowledge, this mutation has not been described. The sequencing of the ninth exon should be proposed as first line molecular analysis for all Moroccan patients with xeroderma pigmentosum.

Keywords: Xeroderma pigmentosum, XPC, Novel mutation, Moroccan

\section{Background}

Xeroderma pigmentosum (XP), (Online Mendelian Inheritance in Man (OMIM) 278700-278780), is a very rare genodermatosis with an estimated prevalence of $1 / 1,000,000$ in United States (USA) and Europe [1] while it is more common in Japan [2] and in other populations with high levels of consanguinity, such as Morocco where the prevalence was estimated to be $1 /$ 80,504 [3].

The diagnosis of XP is based essentially on clinical findings with an early onset of skin abnormalities on individuals' sun-exposed areas during their first years of life. Ocular manifestations limited to the anterior portion are as common as cutaneous lesions. Progressive neurological manifestations are seen in only $25 \%$ of affected individuals [4].

The prognosis of the disease is related to neurological degeneration and skin cancer. Patients with XP have an

\footnotetext{
* Correspondence: y.doubaj@gmail.com

${ }^{1}$ Centre de génomique humaine, Faculté de Médecine et de Pharmacie de Rabat, Université Mohammed V, Rabat, Morocco

${ }^{2}$ Département de Génétique Médicale, Institut National d'Hygiène, 27,

Avenue Ibn Batouta, BP 769, 11400 Rabat, Morocco
}

increased risk of cutaneous neoplasia (basal cell carcinoma, squamous cell carcinoma, and melanoma).

$\mathrm{XP}$ is genetically heterogeneous with nine complementation groups associated with biallelic mutations in nucleotide excision repair (NER) genes or in the deoxyribonucleic acid (DNA) bypass polymerase $P O L H$. In several studies, $X P$ complementation group $C(X P C)$ is the major diseasecausing gene with a recurrent mutation in the Mediterranean region $[5,6]$. According to these findings, the Department of Medical Genetics in Rabat recommends the molecular diagnosis of $\mathrm{XP}$ by screening for the recurrent mutation: c.1643_1644delTG (p.Val548AlafsX25) in the XPC gene.

\section{Case presentation}

The proband is a 21-year-old Moroccan man, the sixth child of healthy consanguineous parents of Moroccan descent with no family history. Pregnancy and delivery were normal. He has a normal motor and mental development. When he was 9-months old, skin changes appeared in photo-exposed areas especially on his face. He has been operated twice for bilateral ocular tumors at the age of 15 -years old. On clinical examination, he presented photophobia and freckling of the skin on his 
face, neck, and limbs. He also had bilateral ocular involvement with conjunctival inflammatory lesions spreading to the cornea. There was no evidence of premalignant skin lesions (actinic keratosis) or apparent neurological abnormalities.

We collected peripheral blood from him and his parents after an informed consent. DNA was extracted with QIAamp DNA Blood Mini Kit (QiaGen). Molecular genetic testing was performed by amplifying the ninth exon of XPC gene by polymerase chain reaction (PCR) to screen for the recurrent mutation, using the following primers: XPC-9F: GGCATCCTCAAGCTCTTCAA and XPC-9R: GGGCTCTGGTATGGTCTCAA. The PCR protocol included an initial denaturation of $95{ }^{\circ} \mathrm{C}$ for 1 minute, followed by 35 cycles of $95{ }^{\circ} \mathrm{C}$ for 15 seconds, $61{ }^{\circ} \mathrm{C}$ for 15 seconds, and $72{ }^{\circ} \mathrm{C}$ for 10 seconds. This led to the identification of a novel homozygous insertion of four bases within the ninth exon of the gene leading to a premature stop codon c.1644_1645insCATG (p.G550Afs*25) (NM_004628). His parents were tested and were found to be heterozygous for the mutation (Fig. 1).

\section{Discussion}

$\mathrm{XP}$ is a rare genodermatosis due to a defect of DNA repair resulting in hypersensitivity to sun and ultraviolet rays. Patients with XP present skin changes especially in photo-exposed areas and have an increased risk of cancer. Cutaneous and ocular lesions are the most common clinical symptoms which can be associated to neurological abnormalities.

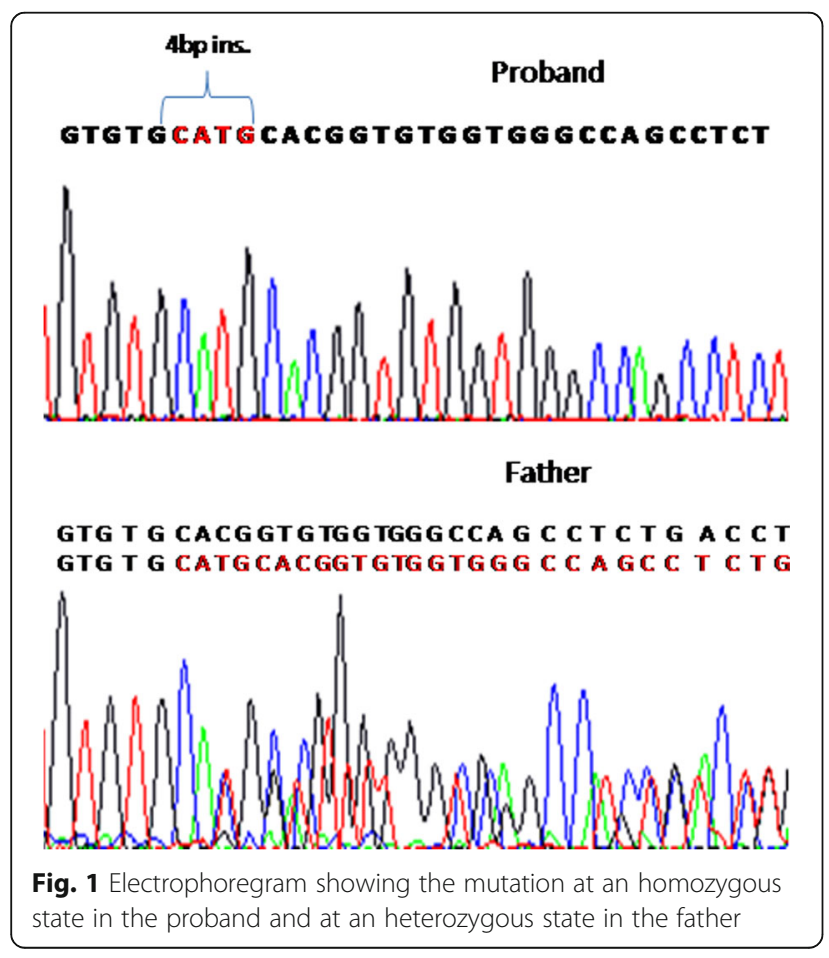

This autosomal recessive disorder is genetically heterogeneous and due to eight complementation groups with defective NER and a variant group (XP-V) with normal NER. To date, nine genes have been associated with XP: XPA, ERCC3 (XPB), XPC, ERCC2 (XPD), DDB2 (XPE), ERCC4 (XPF), ERCC5 (XPG), ERCC1, and POLH $(X P-V)$. The diagnosis of XP is based on clinical features. Molecular genetic testing is possible by looking for mutation at one of the causal genes, but this can be achieved only after characterizing the right gene to study by the determination of the complementation group or linkage study in familial cases.

Soufir et al. reported the genetic analysis of 66 unrelated Maghrebian families with XP (Algeria, Morocco, and Tunisia) [5]. In this cohort, $X P C$ is the major diseasecausing gene concerning $\mathrm{XP}$ in North Africa with the recurrent mutation c.1643_1644delTG (p.Val548AlafsX25) which is responsible for $74 \%$ of all XP [5].

These data allow the molecular diagnosis of Moroccan patients with XP by searching the founder mutation. While sequencing the ninth exon, an insertion of 4-base pairs (4-bp; CATG) between positions 1644_1645 in the complementary DNA (cDNA) was incidentally discovered. This frameshift mutation inducing a stop codon after 25 amino acids is located in the interaction region with RAD23B, which is highly conserved among species according to Mutation Taster Server. Therefore, this variant is very likely the causal mutation of XP in our patient.

About 60 inactivating XPC mutations have been reported in patients with XP complementation group $C$. Most of them are frameshift (deletion and insertion) or nonsense (substitution), leading to a truncated XPC protein. A few splicing and missense mutations are also encountered. According to the Human Gene Mutation Database (HGMD), 25\% of all XPC gene mutations are located in the ninth exon (Fig. 2). To the best of our knowledge, we report on the result of the first insertion type mutation described within exon 9 whose protein sequence corresponds to the domain of interaction with the RAD23B involved in the NER pathway. These data suggest that sequencing exon 9 could be a first line step in a XP molecular diagnosis strategy in addition to specific founder mutations depending on populations. However, there is no obvious correlation between genotype and phenotype or survival found in XP.

Several studies of population-specific founder mutations have been published. Beside the North African mutation identified in $87 \%$ of patients with XP complementation group $C$ [5], other founder mutations were also identified in the Japanese population, one accounting for $90 \%$ of alleles in the XPA gene [2] and four others representing $87 \%$ of XP variant type in Japan [7]. Our patient is a Southern Morocco native and all the reported cases of 


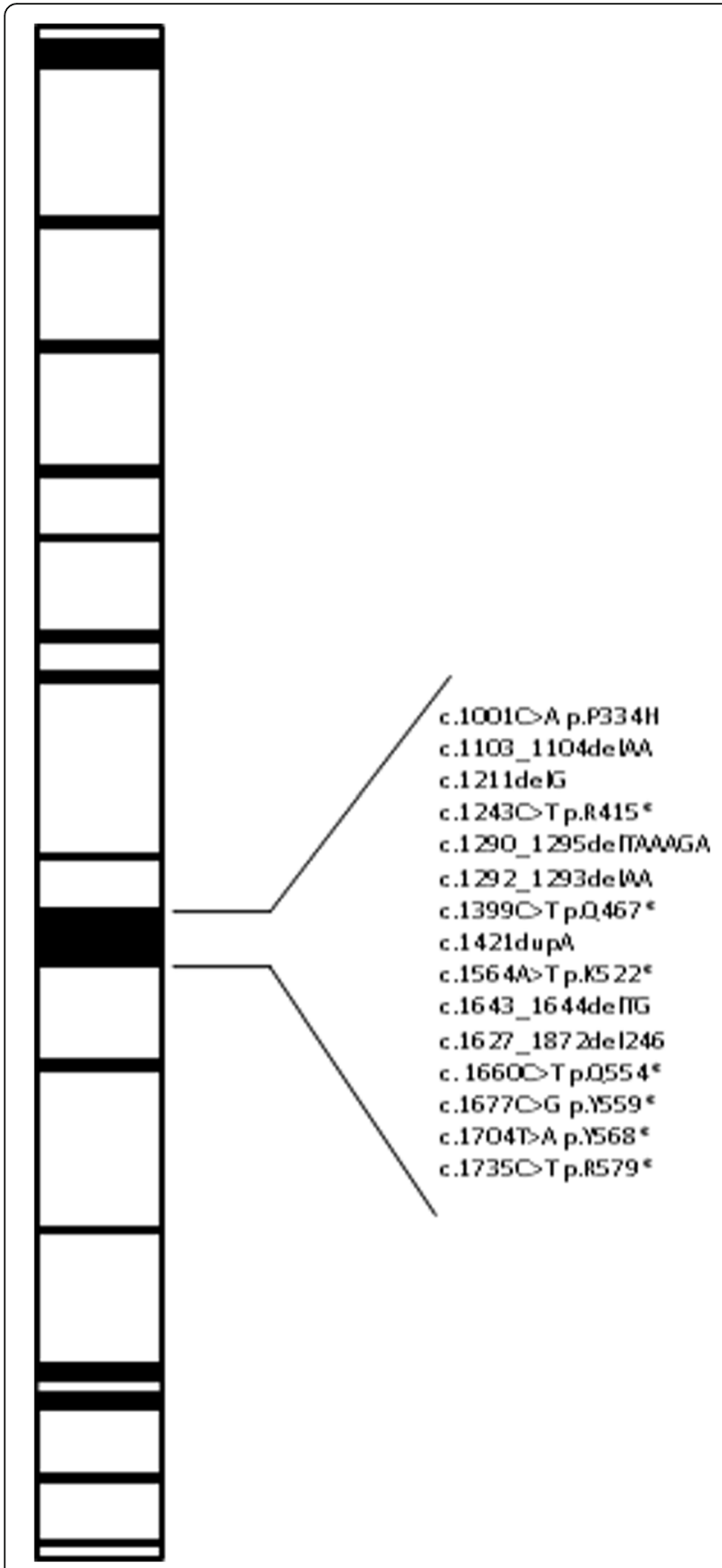

Fig. 2 Recorded mutations in exon 9 in te XPC gene

patients in the previous studies were from North Morocco. Therefore, further patients from South Morocco need to be studied to determine the carrier rate and assess the possibility of a second Moroccan founder mutation.

\section{Conclusions}

Molecular analysis by sequencing the ninth exon of XPC gene enables the majority of causal mutations of the disease to be identified, since it comprises the North African founder mutation and almost $25 \%$ of the other mutations. This laboratory diagnosis strategy enables the provision of genetic counseling and eventually the prenatal diagnosis of the majority of patients with XP in Morocco, and it enables us to identify a novel mutation whose recurrence would be interesting to study.

\section{Acknowledgements}

We would like to thank the patient and his family for their collaboration and also the association which referred the patient to our department.

\section{Funding}

This study had no funding source.

Availability of data and materials

Data sharing not applicable to this article as no datasets were generated or analyzed during the current study.

\section{Authors' contributions}

YD carried out the clinical examination of the patient and drafted the manuscript. WS performed the molecular analysis and helped in the redaction of the manuscript and the figures. FL validated the molecular analysis. AS helped in the validation of the molecular analysis and corrected the manuscript. All authors read and approved the final manuscript.

\section{Competing interests}

The authors declare that they have no competing interests.

\section{Consent for publication}

Written informed consent was obtained from the patient for publication of this case report and any accompanying images. A copy of the written consent is available for review by the Editor-in-Chief of this journal.

\section{Ethics approval and consent to participate}

Ethics approval is deemed unnecessary according to national regulations.

The patient and his parents gave written consent to participate in this study.

\section{Publisher's Note}

Springer Nature remains neutral with regard to jurisdictional claims in published maps and institutional affiliations.

Received: 22 March 2016 Accepted: 6 May 2017

Published online: 15 June 2017

\section{References}

1. Kleijer WJ, Laugel V, Berneburg M, et al. Incidence of DNA repair deficiency disorders in western Europe: xeroderma pigmentosum, Cockayne syndrome and trichothiodystrophy. DNA Repair (Amst). 2008;7:744-50.

2. Hirai $Y$, Kodama Y, Moriwaki S, et al. Heterozygous individuals bearing a founder mutation in the XPA DNA repair gene comprise nearly $1 \%$ of the Japanese population. Mutat Res. 2006:601:171-8.

3. Doubaj Y, Laarabi FZ, Elalaoui SC, Barkat A, Sefiani A. Carrier frequency of the recurrent mutation c.1643_1644delTG in the XPC gene and birth prevalence of the xeroderma pigmentosum in Morocco. J Dermatol. 2012; 39(4):382-4. doi:10.1111/j.1346-8138.2011.01453.x. Epub 2011 Dec 29.

4. Bradford PT, Goldstein AM, Tamura D, Khan SG, Ueda T, Boyle J, Oh KS, Imoto K, Inui H, Moriwaki S, Emmert S, Pike KM, Raziuddin A, Plona TM, DiGiovanna JJ, Tucker MA, Kraemer KH. Cancer and neurologic degeneration in xeroderma pigmentosum: long term follow-up characterises the role of DNA repair. J Med Genet. 2011:48:168-76.

5. Soufir N, Ged C, Bourillon A, Austerlitz F, Chemin C, Stary A, Armier J, Pham D, Khadir K, Roume J, Hadj-Rabia S, Bouadjar B, Taieb A, de Verneuil H, Benchiki H, Grandchamp B, Sarasin A. A prevalent mutation with founder effect in xeroderma pigmentosum group C from north Africa. J Invest Dermatol. 2010;130(6):1537-42. doi:10.1038/jid.2009.409. Epub 2010 Jan 7. 
6. Ben Rekaya M, Messaoud O, Talmoudi F, Nouira S, Ouragini H, Amouri A Boussen H, Boubaker S, Mokni M, Mokthar I, Abdelhak S, Zghal M. High frequency of the V548A fs X572 XPC mutation in Tunisia: implication for molecular diagnosis. J Hum Genet. 2009;54(7):426-9. doi:10.1038/jhg.2009. 50. Epub 2009 May 29.

7. Masaki T, Ono R, Tanioka M, Funasaka Y, Nagano T, Moriwaki S, et al. Four types of possible founder mutations are responsible for $87 \%$ of Japanese patients with Xeroderma pigmentosum variant type. J Dermatol Sci. 2008, 52:144-8

Submit your next manuscript to BioMed Central and we will help you at every step:

- We accept pre-submission inquiries

- Our selector tool helps you to find the most relevant journal

- We provide round the clock customer support

- Convenient online submission

- Thorough peer review

- Inclusion in PubMed and all major indexing services

- Maximum visibility for your research

Submit your manuscript at www.biomedcentral.com/submit 